International Journal of Management (IJM)

Volume 11, Issue 12, December 2020, pp.3249-3266, Article ID: IJM_11_12_304

Available online at http://iaeme.com/Home/issue/IJM?Volume $=11 \&$ Issue $=12$

ISSN Print: 0976-6502 and ISSN Online: 0976-6510

DOI: 10.34218/IJM.11.12.2020.304

\title{
THE MODERATION IMPACT OF PERSONAL INNOVATIVENESS ON THE RELATIONSHIP BETWEEN E-LEARNING STRATEGY IMPLEMENTATION AND HIGH EDUCATION ORGANIZATIONAL PERFORMANCE
}

\author{
Dhoha Younis \\ Lincoln University College, Selangor, Malaysia \\ Divya Midhunchakkaravarthy \\ Lincoln University College, Selangor, Malaysia \\ Osama Isaac \\ Lincoln University College, Selangor, Malaysia \\ Ali Ameen* \\ Lincoln University College, Selangor, Malaysia \\ Balaganesh Duraisamy \\ Lincoln University College, Selangor, Malaysia \\ Midhunchakkaravarthy Janarthanan \\ Lincoln University College, Selangor, Malaysia \\ *Corresponding Author
}

\begin{abstract}
Failure of having strategic management namely the implementation strategy which is considered as a critical stage will result to poor performance and effectiveness in organization. the current study main objective is to examine the impact of strategy implementation on the high education organizational performance with the consideration of personal innovativeness as a moderating variable within the public sector in the Yemen. The present study adopts quantitative research design in its quest to achieve a credible study. As such, questionnaire was developed and used to elicit the respondents' opinion on the effects of strategy implementation on the public high education origination in Yemen. 403 usable responses were analysed using Statistical Package for Social Sciences (SPSS) and PLS (Partial Least Squares) SEM-VB
\end{abstract}


The Moderation Impact of Personal Innovativeness on the Relationship between E-Learning Strategy Implementation and High Education Organizational Performance

(Structural Equation Modelling-Variance Based) was employed to assess the research model. Probability random sampling technique was adopted to gather the required quantitative data. Based on the findings in relation to this objective, the study concluded that the results indicated that e-Learning Strategy Implementation (strategy, structure, and human resources) has a significant and positive impact on organizational performance. Moreover, the Innovativeness strengthens the relationship between $e$ Learning Strategy Implementation and organizational performance. Results would give insights for the public universities in the Yemen.

Key words: Strategy implementation; employee creativity; organizational performance.

Cite this Article: Dhoha Younis, Divya Midhunchakkaravarthy, Osama Isaac, Ali Ameen, Balaganesh Duraisamy and Midhunchakkaravarthy Janarthanan, The Moderation Impact of Personal Innovativeness on the Relationship between E-Learning Strategy Implementation and High Education Organizational Performance, International Journal of Management (IJM), 11(12), 2020, pp. 3249-3266.

http://iaeme.com/Home/issue/IJM?Volume=11\&Issue=12

\section{INTRODUCTION}

Strategic management is one of the important topics and has attracted a great concern among scholars (Wheelen and Hunger 2012). Strategic management has been a concern of private and public organisations (Kang 2006). Failure of having strategic management namely the implementation strategy which is considered as a critical stage will result in poor performance and effectiveness in an organisation (Michaela 2011).

The major objective of Vision 2021 was converting Yemen into a competitive knowledgebased economy (which included creativity, innovative, and financial services). Hence, for improving the organisational performance, strategic planning was regarded as an important parameter.

Moreover, in the Global Innovation Index (2019a) it is shown that the Yemen scores low index among in the world, and that score is not high among the top countries and as innovation is part of performance thus it shows how the Yemen needs to study why the performance of organisations still lagging behind the top countries, which also makes the organisations lag behind the country plan to be one of the top countries in the world.

Strategic management is one of the important topics and has attracted a great concern among scholars (Wheelen and Hunger012). Strategic management has been a concern of private and public organisations (Kang 2006). Failure of having strategic management namely the implementation strategy which is considered as a critical stage will result in poor performance and effectiveness in an organisation (Michaela 2011).

This study focused on the Yemen public sector. Earlier studies were limited to the strategic plan implementation and the Yemen public sector. Though the e-Learning Strategy Implementation process significantly affected the organisational performance, many earlier studies have highlighted a lack of research into the parameters which impacted the proper strategy implementation. In one such study, Andrews et al. (2011) stated that many researchers, who investigated different strategies, mentioned that very few studies assessed the relationship between the e-Learning Strategy Implementation and organisational performance. Furthermore, there was a lack of studies which studied strategic planning in the Middle East and Arabic countries (Elbanna 2008). The results also were not very clear with regards to the e-Learning Strategy Implementation in comparison to the strategy formulation (Aldehayyat and Anchor 2013)(Alhefiti, Ameen, \& Bhaumik, 2019b, 2019a; Alkatheeri, Yazeed; Ameen, Ali; Al- 
Dhoha Younis, Divya Midhunchakkaravarthy, Osama Isaac, Ali Ameen, Balaganesh Duraisamy and Midhunchakkaravarthy Janarthanan

Shibami, 2017; Alkatheeri, Ameen, Isaac, Al-Shibami, \& Nusari, 2020; Alkatheeri, Ameen, Isaac, Alrajawy, \& Bhumik, 2020; Almarri, Ameen, Bhaumik, Alrajawy, \& Khalifa, 2020; Almarri, Ameen, Isaac, Khalifa, \& Bhaumik, 2020; Almatrooshi, Khalifa, Ameen, Hossain, \& Morsy, 2020).

Hence, the main objective of this study was to determine the effect of the e-Learning Strategy Implementation on organisational performance, when Personal innovativeness was regarded as the moderating variable in the Public universities in Yemen.

\section{LITERATURE REVIEW}

\subsection{High Education Organizational Performance (HEOP)}

HEOP was seen to be the most significant variable in management research and was regarded as an important indicator which affected the overall performance of the organization (Gavrea et al., 2011). HEOP was the measure of the prescribed or standard indicators of efficiency, effectiveness and environmental responsibility like productivity, reduction of waste, cycle time, and regulatory compliance. Many people working in the field of management study considered HEOP as a dependent variable. This construct helped the managers and researchers evaluate the organizations over a period of time and thereafter, compare them to their rivals (Richard et al., 2009). Hence, the organizational performance was regarded as an important criterion which helped in assessing the organizations, their environments and activities. This significance was reflected in the fact that the HEOP was used as a dependent variable in earlier studies (Richard et al., 2009). In this study, the researchers have examined the organizational performance concerning 2 factors, i.e., learning and growth and the internal process. The leaning and growth indicated the manner in which the staff was educated and trained and their capacity to acquire knowledge (Hannabarger et al., 2011). Another study (Kaplan and Norton 1996) showed that learning and growth were based on 3 different sources such as people, systems and organizational processes. On the other hand, if the organization wishes to achieve all its publicservice related objectives, it needs to excel in the internal processes. Hence, the organization could fulfil its entire financial objective and increase public satisfaction. These important processes help the departments in the organization fulfil the public expectations and achieve higher outcome (Kaplan and Norton 1996).

\subsection{E-Learning Strategy Implementation (ELSI)}

E-Learning Strategy Implementation includes the collection of all organizational resources and encouraging the staff to fulfil all objectives (Muchira 2013). Any organization uses its resources for determining its scope so that it can acquire a long-term advantage (Johnson et al., 2008). For this purpose, the organizations need to motivate the employees, establish objectives, develop policies and assign some resources for executing the formulated strategies (Zaei, Yarahmadzehi, \& Abtin, 2013). In their study, Abu-Qouod (2006) assessed the e-Learning Strategy Implementation process which included the strategies, structure and the human resources and noted their effect on the organizational performance(Al-Obthani \& Ameen, 2019b, 2019a; Albreiki, Ameen, \& Bhaumik, 2019; Albreki, Ameen, \& Bhaumik, 2019; K. Alghawi, Ameen, \& Bhaumik, 2019b, 2019a; Khalid Alghawi, Ameen, \& Bhaumik, 2019; A. Ameen, Al-Ali, Isaac, \& Mohammed, 2020; A. Ameen, Alfalasi, Gazem, \& Isaac, 2020). Earlier studies have determined the relationship between organizational performance and strategy implementation. In another cross-sectional study, Muchira (2013) observed that the implementation strategy affected organizational performance. They studied different measures like organization goals, past organizational performance and the projective performance of the other businesses and the projected performance of the competitors, before assessing their 
The Moderation Impact of Personal Innovativeness on the Relationship between E-Learning Strategy Implementation and High Education Organizational Performance

performance. Furthermore, Isaac et al. (2016) determined the impact of the e-Learning Strategy Implementation on the organizational performance. Their results indicated that e-Learning Strategy Implementation could significantly and positively affect organizational performance. Some other studies (Ibrahim et al., 2012; Gitonga 2013) also noted an effect of the implementation strategy on the organizational performance. Hence, in this study, the researchers proposed hypothesis 1 as follows:

H1: E-Learning Strategy Implementation shows a positive effect on organizational performance.

\subsection{Personal Innovativeness (INN)}

The people who present excellent ideas are the actual creative thinkers. These creative thinkers are rated on the scale with regards to the quantity and quality of their ideas (Thomas 2005). Personal innovativeness (INN) was vital for the growth of any organization and was dependent on team dynamics. Many studies have highlighted the significance of personal innovativeness in the high education organization. In one such study, Jyoti and Dev (2015) noted a positive association between the personal innovativeness in the high education organization and transformational leadership, which was moderated by the learning orientation(A. A. A. Ameen \& Ahmad, 2012; A. A. B. Ameen \& Ahmad, 2013; A. Ameen \& Ahmad, 2011b, 2011a, 2013, 2014, 2017; A. Ameen, Al-Ali, et al., 2020; A. Ameen, Alfalasi, et al., 2020; A. Ameen, Almari, \& Isaac, 2019; A. Ameen, Almari, Isaac, \& Mohammed, 2019; A. Ameen, Alshamsi, Isaac, Gazem, \& Mohammed, 2021). They collected the data from the employees who worked in the Aircel and Airtel call centers in J\&K (India). Jaiswal and Dhar (2015) also collected a sample which included the dyad of 372 employees along with their supervisors. The results indicated that the transformational leaders fostered a climate which encouraged innovation, thereby promoting personal innovativeness in the high education organization. Furthermore, creative self-efficacy played a moderating role on the relationship between the personal innovativeness in the high education organization and the innovation climate. They noted that the employees with a higher creative self-efficacy displayed creative behavior when they were surrounded by a supportive innovation climate. Bai et al. (2016) observed that knowledge sharing and team conflicts acted as sequential moderators which influenced the cross-level relationship. In this study, the researchers have highlighted the critical role played by the transformational leadership which enabled personal innovativeness in the high education organization.

Many studies investigated the role played by the INN in enhancing organizational performance. Hassan et al. (2013) noted that the personal innovativeness in the high education organization could positively and significantly affect the organizational innovative capacity and firm performance. They carried out convenient sampling for collecting the data from the bank employees who worked in various branches of 7 banks, operating in the Multan city, Pakistan. They collected 164 questionnaires and the data was analyzed using the SPSS 16 software. Chang and Teng (2017) predicted that the extrinsic (i.e., translational leadership) and intrinsic motivators (i.e., creative personality) encouraged the personal innovativeness in the high education organization and the job performance of the employees in the hospitality sector. Their results emphasized that creativity could affect organizational performance. In the case of the service industries, the creativity of the frontline employees was especially important. Siddiqi and Qureshi (2016) observed that if the employees were creative, they could positively affect the firm's performance. The creative employees used organizational resources efficiently, which could improve the overall performance of the firm and increase their market share(Alkatheeri, Ameen, Isaac, Al-Shibami, et al., 2020; Alkatheeri, Ameen, Isaac, Duraisamy, et al., 2020; Haddad et al., 2020)(A. Ameen \& Ahmad, 2014; A. Ameen, Almari, 
Dhoha Younis, Divya Midhunchakkaravarthy, Osama Isaac, Ali Ameen, Balaganesh Duraisamy and Midhunchakkaravarthy Janarthanan

\& Isaac, 2019; A. Ameen, Almari, Isaac, et al., 2019; Osama Isaac, Abdullah, Aldholay, Ameen, et al., 2019; Sudhana, Ameen, \& Isaac, 2020).

The personal innovativeness also acted as a moderating variable. In their study, Li et al. (2018) investigated a sample consisting of 249 employees and 85 supervisors working in 13 different hotels in Shenzhen, China. They noted that the connection between the employee and supervisor along with personal innovativeness could alter the relationship between the affective commitment, perceived organizational support and the employee pre-quitting behavior. In their study, Yang et al. (2016) collected the data from 146 frontline employees who worked in the Chinese banking sector. They tested their theory-driven model and developed some hypotheses. They claimed that their results could help in advancing the knowledge of different disciplines as they noted a linkage between the core concepts. Consequently, the following hypothesis is proposed:

H2: Personal innovativeness strengthens the positive effect of e-Learning Strategy Implementation on organizational performance.

\section{RESEARCH METHOD}

\subsection{Overview of the Proposed Conceptual Framework}

This study proposes a research model based on Resource-Based View Theory and strategic management models postulated in the literature which examined the relationship between eLearning Strategy Implementation consists of (strategy, structure and human resource) and High Education Organizational Performance (consists aspects of financial, clients, internal operational processes, Growth and Learning). Furthermore, the moderation effect of Personal innovativeness on the relationship between e-Learning Strategy Implementation and High Education Organizational Performance Based on the above, the research model for this study is depicted in Figure 3.

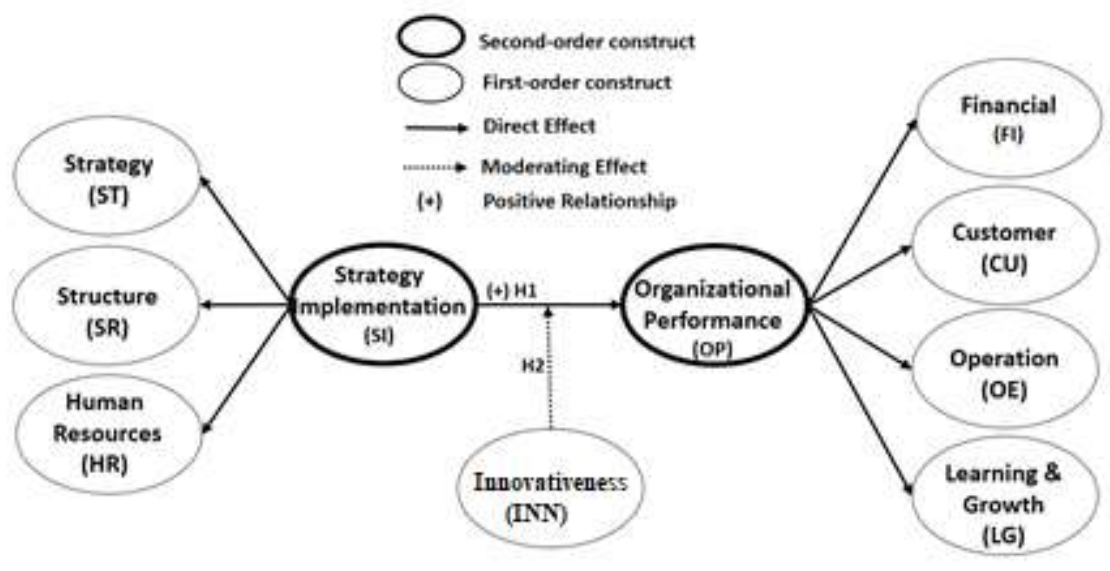

Figure 1 The proposed conceptual framework

\subsection{Development of Instrument and Data collection}

This study has used a quantitative research design for acquiring credible results. For this purpose, the researchers developed a questionnaire and asked the respondents to present their opinion regarding the effect of e-Learning Strategy Implementation on the performance of the Public universities in Yemen. Thereafter, they analysed 403 usable responses with the help of the Statistical Package for Social Sciences (SPSS) software. They applied the PLS (Partial Least Squares)-SEM-VB (Structural Equation Modelling-Variance Based) technique for assessing the research model developed in the study. The respondents formed a small sample of the 
The Moderation Impact of Personal Innovativeness on the Relationship between E-Learning Strategy Implementation and High Education Organizational Performance

employees who worked at the various high education in Yemen. All respondents were selected using a probability random sampling technique. The different variables were determined with the help of a Likert Scale suggested in the earlier reports (Mutahar et al., 2017; Aldholay et al., 2018; Aldholay et al., 2018). Variables were measured using a Likert Scale which recommended in the previous studies (Isaac, Aldholay, Abdullah, \& Ramayah, 2019; Isaac, Abdullah, Ramayah, \& Mutahar, 2018).

\section{DATA ANALYSIS AND RESULTS}

PLS (Partial Least Squares) SEM-VB (Structural Equation Modelling-Variance Based) was employed to assess the research model by utilizing the software SmartPLS 3.0 (Ringle, Wende, $\&$ Becker, 2015). SEM offers more accurate estimates and a simultaneous analysis (Isaac, Abdullah, Aldholay, \& Ameen, 2019; Isaac, Abdullah, Ramayah, \& Mutahar, 2017; Mutahar, Daud, Thurasamy, Isaac, \& Abdulsalam, 2018).

\subsection{Measurement Model Assessment}

The individual Cronbach's alpha, the composite reliability (CR), The average variance extracted (AVE), and the factor loadings exceeded the suggested value (Kline, 2010; Hair, Black, Babin, \& Anderson, 2010) as illustrated in Table 1.

Table 1 Measurement model assessmen

\begin{tabular}{|c|c|c|c|c|c|c|c|}
\hline Constructs & Item & $\begin{array}{c}\text { Loading } \\
(>0.7)\end{array}$ & M & SD & $\begin{array}{c}\alpha \\
(>0.7)\end{array}$ & $\begin{array}{c}\text { CR } \\
(>0.7)\end{array}$ & $\begin{array}{c}\text { AVE } \\
(>0.5)\end{array}$ \\
\hline \multirow{4}{*}{$\begin{array}{c}\text { Strategy } \\
\text { (ST) }\end{array}$} & ST1 & 0.873 & \multirow{4}{*}{3.52} & \multirow{4}{*}{1.12} & \multirow{4}{*}{0.847} & \multirow{4}{*}{0.897} & \multirow{4}{*}{0.686} \\
\hline & ST2 & 0.809 & & & & & \\
\hline & ST3 & 0.836 & & & & & \\
\hline & ST4 & 0.793 & & & & & \\
\hline \multirow{4}{*}{$\begin{array}{l}\text { Structure } \\
\quad(\mathrm{SR})\end{array}$} & SR1 & 0.878 & \multirow{4}{*}{3.30} & \multirow{4}{*}{1.13} & \multirow{4}{*}{0.855} & \multirow{4}{*}{0.902} & \multirow{4}{*}{0.698} \\
\hline & SR2 & 0.817 & & & & & \\
\hline & SR3 & 0.827 & & & & & \\
\hline & SR4 & 0.818 & & & & & \\
\hline \multirow{4}{*}{$\begin{array}{l}\text { Human } \\
\text { Resources } \\
\text { (HR) }\end{array}$} & HR1 & 0.824 & \multirow{4}{*}{3.32} & \multirow{4}{*}{1.16} & \multirow{4}{*}{0.843} & \multirow{4}{*}{0.895} & \multirow{4}{*}{0.680} \\
\hline & HR2 & 0.854 & & & & & \\
\hline & HR3 & 0.824 & & & & & \\
\hline & $\mathrm{HR} 4$ & 0.797 & & & & & \\
\hline \multirow{4}{*}{$\begin{array}{c}\text { Personal } \\
\text { innovativeness } \\
\text { (INN) }\end{array}$} & INN1 & 0.956 & \multirow{4}{*}{3.13} & \multirow{4}{*}{1.23} & \multirow{4}{*}{0.956} & \multirow{4}{*}{0.964} & \multirow{4}{*}{0.870} \\
\hline & INN2 & 0.924 & & & & & \\
\hline & INN3 & 0.953 & & & & & \\
\hline & INN4 & 0.897 & & & & & \\
\hline \multirow{5}{*}{$\begin{array}{l}\text { Financial } \\
(\mathrm{FI})\end{array}$} & FI1 & 0.936 & \multirow{5}{*}{3.59} & \multirow{5}{*}{1.06} & & & \\
\hline & FI2 & 0.908 & & & & & \\
\hline & FI3 & 0.702 & & & 0.889 & 0.926 & 0.759 \\
\hline & FI4 & 0.917 & & & & & \\
\hline & FI5 & Deleted & & & & & \\
\hline & CU1 & 0.907 & & & & & \\
\hline & CU2 & 0.882 & & & & & \\
\hline Customer & CU3 & 0.737 & 3.59 & 1.09 & 0.892 & 0.922 & 0.704 \\
\hline & CU4 & 0.749 & & & & & \\
\hline & CU5 & 0.903 & & & & & \\
\hline & OE1 & Deleted & & & & & \\
\hline & OE2 & 0.839 & & & & & \\
\hline $\begin{array}{l}\text { Operation } \\
(\mathrm{OE})\end{array}$ & OE3 & 0.972 & 3.33 & 1.15 & 0.956 & 0.969 & 0.886 \\
\hline & OE4 & 0.972 & & & & & \\
\hline & OE5 & 0.975 & & & & & \\
\hline & LG1 & 0.715 & & & & & \\
\hline Learning \& & LG2 & 0.817 & & & & & \\
\hline Growth & LG3 & 0.780 & 3.50 & 1.00 & 0.846 & 0.890 & 0.620 \\
\hline (LG) & LG4 & 0.835 & & & & & \\
\hline & LG5 & 0.783 & & & & & \\
\hline
\end{tabular}

Note: $\mathrm{M}=$ Mean; $\mathrm{SD}=$ Standard Deviation, $\alpha=$ Cronbach's alpha; $\mathrm{CR}=$ Composite Reliability, AVE $=$ Average Variance Extracted. Key: ST: Strategy, SR: Structure, HR: Human Resources, INN: Personal Innovativeness, FI: Financial, CU: Customer, OE: Operation, LG: Learning \& Growth 
Dhoha Younis, Divya Midhunchakkaravarthy, Osama Isaac, Ali Ameen, Balaganesh Duraisamy and Midhunchakkaravarthy Janarthanan

Fornell-Larcker was used to test the discriminant validity, table 2 shows that all constructs of model fulfilled satisfactorily, it was discovered that the AVEs' square root on the diagonals is bigger than the correlations among constructs (Fornell \& Larcker, 1981; Chin, 1998; Hair et al., 2017).

Table 2 Fornell-Larcker criterion

\begin{tabular}{c|cccccccc}
\hline & $C U$ & $I N N$ & $F I$ & $H R$ & $L G$ & $O E$ & $S R$ & $S T$ \\
\hline CU & $\mathbf{0 . 8 3 9}$ & & & & & & & \\
INN & 0.063 & $\mathbf{0 . 9 3 3}$ & & & & & & \\
FI & 0.611 & 0.091 & $\mathbf{0 . 8 7 1}$ & & & & & \\
HR & 0.539 & 0.068 & 0.551 & $\mathbf{0 . 8 2 5}$ & & & & \\
LG & 0.574 & 0.098 & 0.583 & 0.557 & $\mathbf{0 . 7 8 7}$ & & & \\
OE & 0.511 & 0.041 & 0.491 & 0.521 & 0.505 & $\mathbf{0 . 9 4 1}$ & & \\
SR & 0.462 & 0.131 & 0.506 & 0.475 & 0.532 & 0.535 & $\mathbf{0 . 8 3 6}$ & $\mathbf{0 . 8 2 9}$ \\
ST & 0.520 & 0.103 & 0.595 & 0.639 & 0.603 & 0.496 & 0.563 & \\
\hline
\end{tabular}

Note: Diagonals represent the square root of the average variance extracted while the other entries represent the correlations. Key: ST: Strategy, SR: Structure, HR: Human Resources, INN: Personal Innovativeness, FI: Financial, CU: Customer, OE: Operation, LG: Learning \& Growth

\subsection{Structural Model Assessment}

The structural model can be tested by computing beta $(\beta), R^{2}$, and the corresponding $t$-values via a bootstrapping procedure with a resample of 5,000 (Hair, Hult, Ringle, \& Sarstedt, 2017).

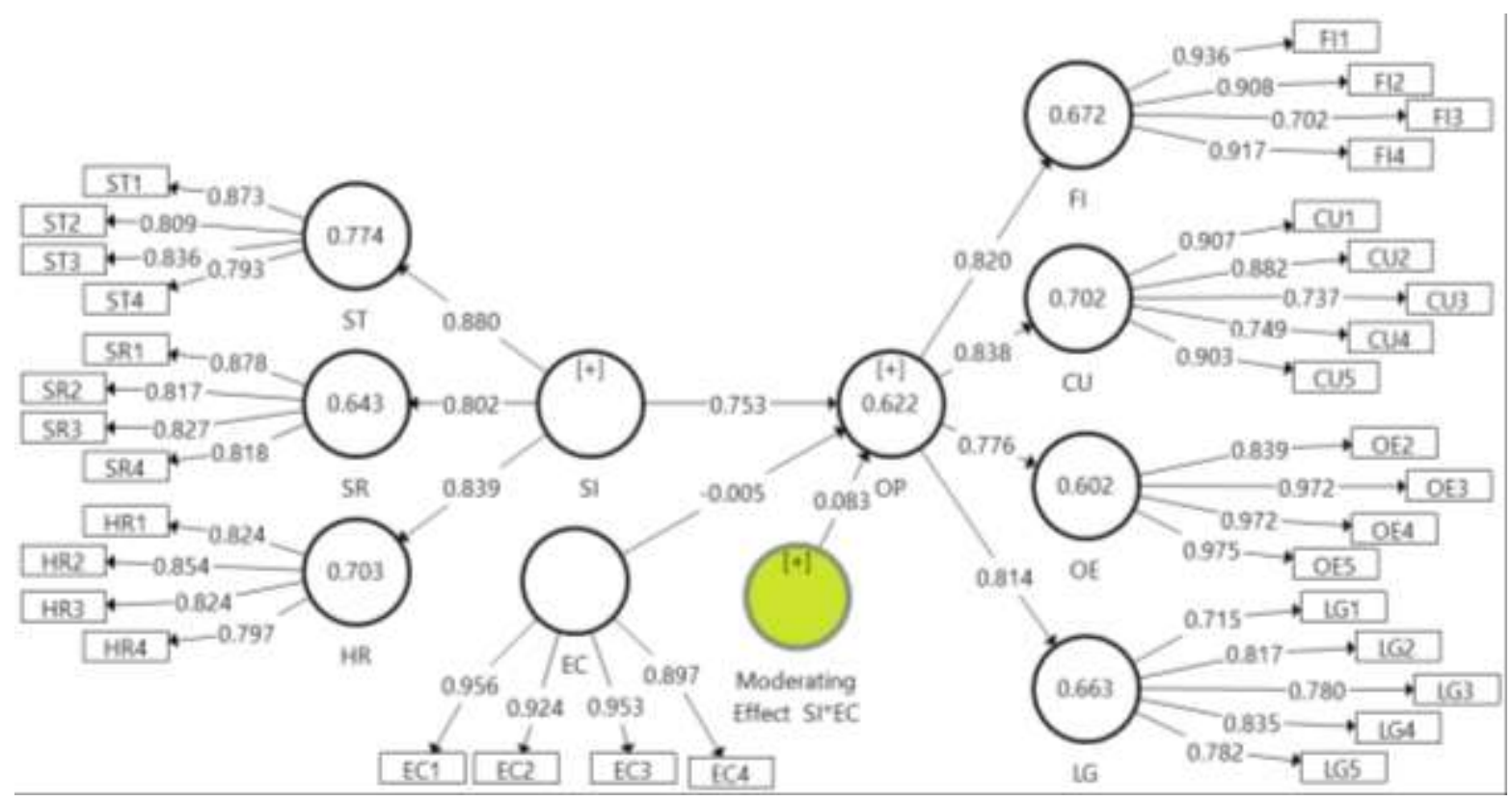

Key: ELSI: Strategy Implementation, ST: Strategy, SR: Structure, HR: Human Resources, INN: Personal Innovativeness , HEOP: High Education Organizational Performance, FI: Financial, CU: Customer, OE: Operation, LG: Learning \& Growth

Figure 2 PLS algorithm results

\subsubsection{Direct Effect Hypotheses}

Figure 4 and Table 3 showing the results of the hypothesis tests. E-Learning Strategy Implementation positively influences High Education Organizational Performance. Hence, H1 is accepted with $(\beta=0.753, \mathrm{t}=26.023, \mathrm{p}<0.001)$. 
The Moderation Impact of Personal Innovativeness on the Relationship between E-Learning Strategy Implementation and High Education Organizational Performance

E-Learning Strategy Implementation explains sixty-two percent of the variance in High Education Organizational Performance. The values of $R^{2}$ have an acceptable level of explanatory power, indicating a substantial model (Cohen, 1988; Chin, 1998).

Table 3 Result of Direct Effect Hypotheses

\begin{tabular}{cccccccc}
\hline \hline \multirow{2}{*}{ Hypothesis } & \multirow{2}{*}{ Relationship } & $\begin{array}{l}\text { Std } \\
\text { Beta }\end{array}$ & Std Error & t-value & p-value & Decision & $\mathrm{R}^{2}$ \\
\hline H3 & ELSI $\rightarrow$ HEOP & 0.753 & 0.029 & 26.023 & 0.000 & Supported & 0.62 \\
\hline \hline
\end{tabular}

Key: ELSI: Strategy Implementation, HEOP: High Education Organizational Performance.

\subsubsection{Moderating Effect Hypotheses}

As shown in Figure 2 and Table 4, three sub-hypotheses were tested for the four main hypotheses namely: (1) Testing the causal effect of predictor on outcome. (2) Testing the causal effect of moderating on outcome. (3) Testing the causal effect of interaction (predictor*Moderating) on outcome. The moderation assessment of this study was tested through hypotheses H2. A bootstrapping procedure with a resample of 5,000 was also performed to assess the interaction effect. The results as shown in Figure 3 and Table 4 find that Personal innovativeness moderates (strengthen) the positive impact of e-Learning Strategy Implementation on High Education Organizational Performance $(\beta=0.083, \mathrm{t}=1.703, \mathrm{p}$ $<0.05)$, so, $\mathrm{H} 2$ is accepted.

Table 4 Result of Moderating Effect Hypotheses

\begin{tabular}{lllllll}
\hline & Std Beta & Std Error & t-value & p-value & Decision \\
\hline & H2.a: ELSI $\rightarrow$ HEOP & 0.753 & 0.028 & 26.704 & 0.000 & \\
H2 & $\begin{array}{l}\text { H2.b: INN } \rightarrow \text { HEOP } \\
\text { H2.c: }\end{array}$ & -0.005 & 0.049 & 0.098 & 0.461 & Supported \\
& & & & & 0.044 & \\
\hline
\end{tabular}

Key: ELSI: Strategy Implementation, INN: Personal Innovativeness , HEOP: High Education Organizational Performance

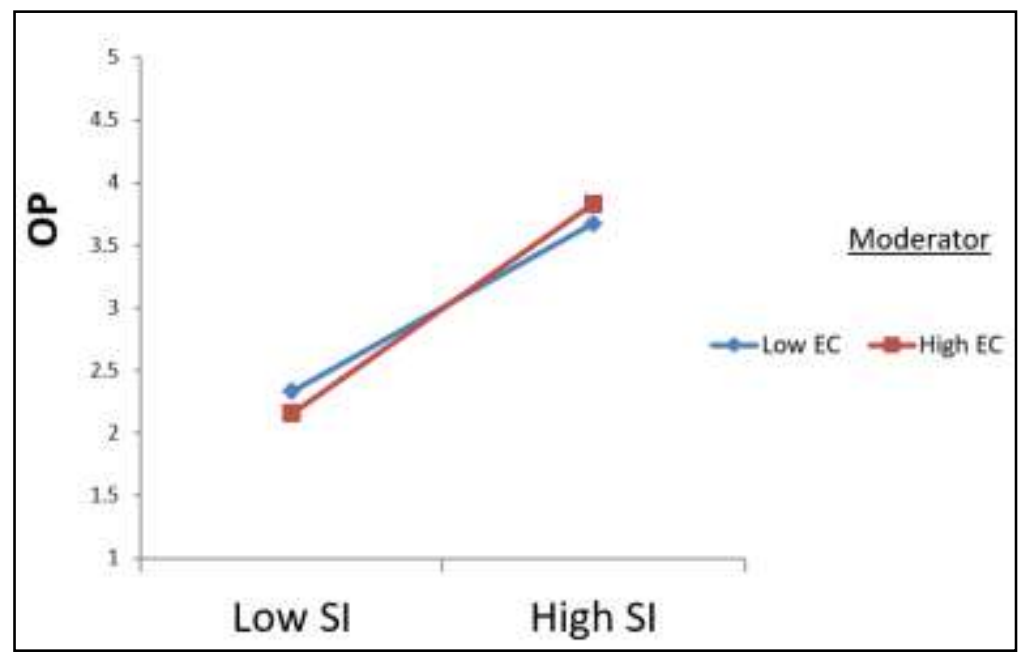

Key: ELSI: Strategy Implementation, INN: Personal Innovativeness , HEOP: High Education Organizational Performance

Figure 3 Moderating effects result

\section{DISCUSSION}

The main objective of the study is to investigate the effect of e-Learning Strategy Implementation (Strategy, structure, and human resources) on High Education Organizational 
Dhoha Younis, Divya Midhunchakkaravarthy, Osama Isaac, Ali Ameen, Balaganesh Duraisamy and Midhunchakkaravarthy Janarthanan

Performance within public sector in the Yemen, the high education. Moreover, the moderation effect of the Personal innovativeness on the relationship between the e-Learning Strategy Implementation and High Education Organizational Performance.

The first objective focuses on examinations of the association between strategy implementations (strategies, human resources, structures) and organizational performances in Yemen public sector institutions, the high education departments in Yemen. A single question and hypothesis pair were devised to attain this goal. Statistical analyses were conducted for testing $\mathrm{H} 1$, which implies a significant association between institutional strategy implementations (strategies, human resources, structures) and organizational performance. All hypotheses were tested using SMART PLS. The results demonstrate that the associations between the strategies align with the results of Gitonga (2013) who established the influence of implementation strategies on organizational performances. This finding was validated by (Aligholi \& Gheshlagh, 2014; Ibrahim, Sulaiman, Al Kahtani, \& Abu-Jarad, 2012; Muchira, 2013; Njagi \& Kombo, 2014; Owolabi \& Makinde, 2012; Schurer Coldiron, 2015) who emphasized implementation strategies linked to organizational performances. It was proposed that public sector organizations may need to put more attention on strategy implementations (strategies, human resources, structures) to enhance organizational innovation. The hypothesis was backed with $(\beta=0.753, \mathrm{t}=26.023, \mathrm{p}<0.001)$, indicating the meaningful effects of strategy implementations (strategies, human resources, structures) on organizational performances. The results suggest that such strategy implementations continue to affect public sector organizational performances in the Yemen. The second objective in this study is therefore achieved.

The second goal of the research focuses on testing for the moderating influence of Innovativeness on the association between organizational performance and implementation strategy, among the high education staffs in in Yemen. A single question and hypothesis pair were devised to attain this goal. Statistical analyses were conducted for testing H2. The findings showed that the association between organizational performance and implementation strategy is strengthened (moderated) by such employee creativity. This is shown in that the more creative staff are, the stronger the influence of e-Learning Strategy Implementation on organizational performance, particularly in Yemen public sector institutions as represented by the high education. The implication is that higher managers must focus on Innovativeness in order to enhance organizational e-Learning Strategy Implementation and thereby enhance organizational performance. Ultimately, the fourth goal was attained. The results suggest that Innovativeness has moderating effects on the association between organizational performance and strategy implementation.

\section{IMPLICATIONS}

The key contribution of this study regards the role of implementation strategy in influencing High Education Organizational Performance, wherein integrated Innovativeness roles act as moderating factors on associations between strategy implementation, and High Education Organizational Performance. The research contributes critical theoretical value by highlighting those components of strategic management that contribute significantly to organizational performances. It provides evidence from synthesized empirical research, theoretical constructs, and concepts derived from various learning disciplines. This study aims to contribute to current understandings of strategic management, implementation strategy, and High Education Organizational Performances, as well as enable a further extension of research in this field. The research has also revalidated the applicability of this theory to government organizations and developing states. It will certainly offer better insights for other researchers, which may be employed as reference material for further investigation. 
The Moderation Impact of Personal Innovativeness on the Relationship between E-Learning

Strategy Implementation and High Education Organizational Performance

This research is critical from both a scientific and practical standpoint, as a reference for other researchers in the field of public sector administration. It focuses on a specific public sector institution, the high education, as well as other stakeholders with critical information and insight on current practices in strategy formulation and implementation in the high education in Yemen. The results are expected to enhance the application of such strategies by the department for delivering services properly. This research could enhance institutional efficiency, reduce waste, and lead to higher utilization of idle potentials, which should in turn enable the justice organization to offer more modern services at lower cost, thus using the available budget efficiently, whatever level it may be set to later. The research findings could well serve as a field reference in this area.

\section{FUTURE RESEARCH \& LIMITATIONS}

This study uses cross-sectional for data gathered; the longitudinal method might enhance the understanding of the relationship between variables variables (Isaac, Abdullah, Ramayah, Mutahar, \& Alrajawy, 2017; Isaac, Abdullah, Ramayah, \& Mutahar Ahmed, 2017). Related studies recommended to conduct cross-cultural studies to investigate the relationship between variables (Isaac, Abdullah, Ramayah, \& Mutahar, 2017a; Isaac, Masoud, Samad, \& Abdullah, 2016; Alrajawy, Mohd Daud, Isaac, \& Mutahar, 2016; Alrajawy et al., 2018; Alrajawy, Daud, Isaac, \& Mutahar, 2017).

\section{CONCLUSION}

This study aims to increase knowledge in the field of strategic management and organizational performance regarding the Yemen. Through examinations of the effects of implementation strategy on the performances of public-sector organizations, the research adds valuable knowledge to the field of public sector as well as academic studies regarding the Yemen. Furthermore, the research adds to understanding regarding the importance of the moderating effects of Innovativeness roles in public-sector organizations, the high education in Yemen. The findings highlight the identified objectives and also the research contributions of various parties. Despite the presence of various limitations in this research, the findings have been mostly encouraging, for these have shed more light on this field. Organizations should increase spending on research and development in order to increase the organizational effectiveness (Osama Isaac, Abdullah, Ramayah, Mutahar, \& Alrajawy, 2018; Isaac, Abdullah, Ramayah, \& Mutahar, 2017b; Mutahar, Mohd Daud, Ramayah, Isaac, \& Alrajawy, 2017).

\section{REFERENCES}

[1] Abu-Qouod, G. (2006). The Role of Strategic Management towards Improving Institutional Performance in Public Organizations in the Hashemite Kingdom of Jordan. Cairo UniversityEygpt.

[2] Al-Obthani, F., \& Ameen, A. (2019a). Association between Transformational Leadership and Smart Government among Employees in UAE Public Organizations. International Journal on Emerging Technologies, 10(1a), 98-104.

[3] Al-Obthani, F., \& Ameen, A. (2019b). Influence of Overall Quality and Innovativeness on Actual Usage of Smart Government: An Empirical Study on the UAE Public Sector. International Journal on Emerging Technologies, 10(1a), 141-146.

[4] Albreiki, S., Ameen, A., \& Bhaumik, A. (2019). Impact of Internal Government Efficiency and Service Delivery Infrastructure on the Smart Government Effectiveness in UAE. International Journal on Emerging Technologies, 10(1a), 124-131. 
Dhoha Younis, Divya Midhunchakkaravarthy, Osama Isaac, Ali Ameen, Balaganesh Duraisamy and Midhunchakkaravarthy Janarthanan

[5] Albreki, S., Ameen, A., \& Bhaumik, A. (2019). The Influence of Quality of Knowledge Management on the Smart Government: Literature Review. International Journal on Emerging Technologies, 10(1a), 105-114.

[6] Aldehayyat, J. S., \& Anchor, J. R. (2013). Strategic planning tools and techniques in Jordan: awareness and use. Journal of Interprofessional Care, 27(1), 10-17. https://doi.org/10.1108/JAEE-09-2015-0064

[7] Aldholay, A. H., Abdullah, Z., Ramayah, T., Isaac, O., \& Mutahar, A. M. (2018). Online learning usage and performance among students within public universities in Yemen. 12(2). https://doi.org/10.1504/IJSS.2018.10012964

[8] Aldholay, A. H., Isaac, O., Abdullah, Z., \& Ramayah, T. (2018). The Role of Transformational Leadership as a Mediating Variable in DeLone and McLean Information System Success Model: The Context of Online Learning usage in Yemen. Telematics and Informatics. https://doi.org/10.1016/j.tele.2018.03.012

[9] Alghawi, K., Ameen, A., \& Bhaumik, A. (2019a). Empirical study of the UAE-based smart government's characteristics and its effect on performance quality. International Journal on Emerging Technologies, 10(1).

[10] Alghawi, K., Ameen, A., \& Bhaumik, A. (2019b). The role of smart government characteristics for enhancing UAE's public service quality. International Journal on Emerging Technologies, $10(1)$.

[11] Alghawi, Khalid, Ameen, A., \& Bhaumik, A. (2019). The Role of Smart Government Characteristics for Enhancing UAE's Public Service Quality. International Journal on Emerging Technologies, 10(1a), 1-7.

[12] Alhefiti, S., Ameen, A., \& Bhaumik, A. (2019a). The Impact of the Leadership and Strategy Management on Organizational Excellence: Moderating role of Organizational Culture. Journal of Advanced Research in Dynamical and Control Systems, 11(06), 748-759.

[13] Alhefiti, S., Ameen, A., \& Bhaumik, A. (2019b). The influence of transformational leadership on organizational creative problem solving capacity. Journal of Advanced Research in Dynamical and Control Systems, 11(06), 736-748. https://doi.org/10.5937/skolbiz2-10122

[14] Aligholi, M., \& Gheshlagh, Y. B. (2014). Evaluation of the Influence of Strategic Management Dimensions on Organizational Performance. Journal of Applied Environmental and Biological Sciences, 4(9), 78-86.

[15] Alkatheeri, Yazeed; Ameen, Ali; Al-Shibami, A. (2017). The Role of Big Data in Improving Decision-Making Based on Management Information Systems: Conceptual Framework Proposed. 1st International Conference on Management and Human Science 2017, (July), 2017. Kuala Lumpur, Malaysia.

[16] Alkatheeri, Y., Ameen, A., Isaac, O., Al-Shibami, A., \& Nusari, M. (2020). The Mediation Effect of Management Information Systems on the Relationship between Big Data Quality and Decision making Quality. Test Engineering and Management, 82(Jan-Feb), 12065-12074.

[17] Alkatheeri, Y., Ameen, A., Isaac, O., Alrajawy, I., \& Bhumik, A. (2020). The Effect of Knowledge Management Quality and Management Information Systems on Decision Making Quality. Test Engineering and Management, 82(Jan-Feb), 12075-12085.

[18] Alkatheeri, Y., Ameen, A., Isaac, O., Duraisamy, B., Nusari, M., Gamal, S Khalifa, A., ... Khalifa, G. S. A. (2020). The Effect of Big Data on the Quality of Decision-Making in Abu Dhabi Government Organisations. In B. V. Sharma N., Chakrabarti A. (Ed.), Advances in 
The Moderation Impact of Personal Innovativeness on the Relationship between E-Learning Strategy Implementation and High Education Organizational Performance

Intelligent Systems and Computing (AISC, volu, Vol. 1016, pp. 231-248). https://doi.org/10.1007/978-981-13-9364-8_18

[19] Almarri, H., Ameen, A., Bhaumik, A., Alrajawy, I., \& Khalifa, G. S. A. (2020). The Mediating Effect of Facilitating Conditions on The Relationship Between Actual Usage of Online Social Networks (OSN) and User Satisfaction. International Journal of Psychosocial Rehabilitation, 24(06), 6389-6400.

[20] Almarri, H., Ameen, A., Isaac, O., Khalifa, G. S. A., \& Bhaumik, A. (2020). Antecedents And Outcomes of Online Social Networks (OSN) Usage among Public Sector Employees. International Journal of Psychosocial Rehabilitation, 24(06), 6373-6388.

[21] Almatrooshi, M. J. A. A., Khalifa, G. S. A., Ameen, A., Hossain, S., \& Morsy, M. A. (2020). The Role of Knowledge Oriented Leadership and Knowledge Sharing to Manage the Performance of Ministry of Interior in UAE. International Journal on Recent Trends in Business and Tourism, 4(2), 9-17.

[22] Alrajawy, I., Daud, N. M., Isaac, O., \& Mutahar, A. M. (2016). Mobile Learning in Yemen Public Universities: Factors Influence Student's Intention to Use. The 7th International Conference Postgraduate Education (ICPE7), 1050-1064. Shah Alam, Malaysia.

[23] Alrajawy, I., Daud, N. M., Isaac, O., \& Mutahar, A. M. (2017). Examine Factors Influencing the Intention to use Mobile Learning in Yemen Public Universities. Asian Journal of Information Technology, 16(2), 287-297. https://doi.org/10.3923/ajit.2017.287.297

[24] Alrajawy, I., Isaac, O., Ghosh, A., Nusari, M., Al-Shibami, A. H., \& Ameen, A. (2018). Determinants of Student's Intention to Use Mobile Learning in Yemeni Public Universities: Extending the Technology Acceptance Model (TAM) with Anxiety. In International Journal of Management and Human Science (IJMHS) (Vol. 2).

[25] Ameen, A. A. A., \& Ahmad, K. (2012). Towards Harnessing Financial Information Systems in Reducing Corruption: A Review of Strategies. Australian Journal of Basic and Applied Sciences, 6(8), 500-509.

[26] Ameen, A. A. B., \& Ahmad, K. (2013). A Conceptual Framework of Financial Information Systems to reduce corruption. Journal of Theoretical and Applied Information Technology, 54(1), 59-72.

[27] Ameen, A., \& Ahmad, K. (2011a). The Role of Finance Information Systems in anti financial corruptions: A theoretical review. 11 International Conference on Research and Innovation in Information Systems (ICRIIS'11, 267-272. https://doi.org/10.1109/ICRIIS.2011.6125725

[28] Ameen, A., \& Ahmad, K. (2011b). The Role of Finance Information Systems in Anti financial Corruptions: A Theoretical Review. 11 International Conference on Research and Innovation in Information Systems (ICRIIS'11, 267-272. https://doi.org/10.1109/ICRIIS.2011.6125725

[29] Ameen, A., \& Ahmad, K. (2013). Proposing Strategy for Utilizing Financial Information Systems in Reducing Corruption. 3rd International Conference on Research and Innovation in Information Systems - 2013 (ICRIIS'13), 2013(1), 75-80.

[30] Ameen, A., \& Ahmad, K. (2014). A Systematic Strategy for Harnessing Financial Information Systems in Fighting Corruption Electronically. Knowledge Management International Conference (KMICe) 2014, 12 - 15 August 2014, Malaysia, 12-15. Retrieved from http://www.kmice.cms.net.my/ 
Dhoha Younis, Divya Midhunchakkaravarthy, Osama Isaac, Ali Ameen, Balaganesh Duraisamy and Midhunchakkaravarthy Janarthanan

[31] Ameen, A., \& Ahmad, K. (2017). Information Systems Strategies to Reduce Financial Corruption. In S. M. Benlamri R. (Ed.), Springer Proceedings in Business and Economics (Vol. 1, pp. 731-740). https://doi.org/10.1007/978-3-319-43434-6_65

[32] Ameen, A., Al-Ali, D., Isaac, O., \& Mohammed, F. (2020). Examining relationship between service quality, user satisfaction, and performance impact in the context of smart government in UAE. International Journal of Electrical and Computer Engineering (IJECE), 10(6), 60266033. https://doi.org/10.11591/ijece.v10i6.pp6026-6033

[33] Ameen, A., Alfalasi, K., Gazem, N. A., \& Isaac, O. (2020). Impact of System Quality, Information Quality, and Service Quality on Actual Usage of Smart Government. 2019 First International Conference of Intelligent Computing and Engineering (ICOICE), 1-6. https://doi.org/10.1109/ICOICE48418.2019.9035144

[34] Ameen, A., Almari, H., \& Isaac, O. (2019). Determining underlying factors that influence online social network usage among public sector employees in the UAE. In Fathey M. Faisal Saeed, Nadhmi Gazem (Ed.), Advances in Intelligent Systems and Computing (3rd ed., Vol. 843, pp. 945-954). https://doi.org/10.1007/978-3-319-99007-1_87

[35] Ameen, A., Almari, H., Isaac, O., \& Mohammed, F. (2019). Investigating the Key Factors Influencing the Use of Online Social Networks in Public Sector Context in the UAE. International Journal of Innovation, 7(3), 392-411. https://doi.org/10.5585/iji.v7i3.347

[36] Ameen, A., Alshamsi, S., Isaac, O., Gazem, N. A., \& Mohammed, F. (2021). Impact of Inspirational Motivation on Organizational Innovation (Administrative Innovation, Process Innovation, and Product Innovation). In Advances on Smart and Soft Computing (pp. 613-623). https://doi.org/10.1007/978-981-15-6048-4_53

[37] Andrews, R., Boyne, G., \& Walker, R. (2011). The Impact of Management on Administrative and Survey Measures of Organizational Performance. In Public Management Review (Vol. 13). https://doi.org/10.1080/14719037.2010.532968

[38] Bai, Y., Lin, L., \& Ping, P. (2016). How to enable employee creativity in a team context: A cross-level mediating process of transformational leadership. Journal of Business Research, 69(9), 3240-3250. https://doi.org/10.1016/j.jbusres.2016.02.025

[39] Bhattacharjee, S., Chakkaravarthy, M., \& Chakkaravarthy, D. M. (2019). GPU-based integrated security system for minimizing data loss in big data transmission. In Data Management, Analytics and Innovation (pp. 421-435). Springer, Singapore.

[40] Bhattacharjee, S., Rahim, L. B. A., Ramadhani, A. W., \& Midhunchakkravarthy, D. (2020). A Study on Seismic Big Data Handling at Seismic Exploration Industry. In Intelligent Computing and Innovation on Data Science (pp. 421-429). Springer, Singapore.

[41] Chang, J., \& Teng, C. (2017). International Journal of Hospitality Management Intrinsic or extrinsic motivations for hospitality employees creativity: The moderating role of organization-level regulatory focus. International Journal of Hospitality Management, 60, 133 141. https://doi.org/10.1016/j.ijhm.2016.10.003

[42] Cheng, D., Liu, G., Qian, C., \& Song, Y.-F. (2013). Customer Acceptance of Internet Banking: Integrating Trust and Quality with UTAUT Model. IEEE, 1(1), 383-388.

[43] Cheng, Y.-M. (2014). Exploring the intention to use mobile learning: the moderating role of personal innovativeness. Journal of Systems and Information Technology, 16(1), 40-61. https://doi.org/10.1108/JSIT-05-2013-0012 
The Moderation Impact of Personal Innovativeness on the Relationship between E-Learning Strategy Implementation and High Education Organizational Performance

[44] Chin, W. W. (1998a). Issues and opinion on structural equation modeling. MIS Quarterly, 22(1), $7-16$.

[45] Chin, W. W. (1998b). The partial least squares approach to structural equation modeling. In G. A. Marcoulides (Ed.), Modern methods for business research (pp. 295-358). New Jersey: Lawrence Erlbaum Associates. Mahwah, NJ: Lawrence Erlbaum.

[46] Cohen, J. (1988). Statistical power analysis for the behavioral sciences (2nd ed.). Hillsdale, Lawrence Erlbaum Associates.

[47] Elbanna, S. (2008). Planning and participation as determinants of strategic planning effectiveness: Evidence from the Arabic context. Management Decision, 46(5), 779-796. https://doi.org/10.1108/00251740810873761

[48] Fornell, C., \& Larcker, D. F. (1981). Evaluating structural equation models with unobservable variables and measurement error. Journal of Marketing Research, 18(1), 39-50.

[49] Gavrea, C., Ilies, L., \& Stegerean, R. (2011). Determinants of organizational performance: The case of Romania. Management \& Marketing, 6(2), 285-300.

[50] GITONGA, M. N. (2013). Effects of strategic plan implementation on organizational performance: a case study of Nakuru Water and Sanitation Services Company (NAWASSCO). KABARAK UNIVERSITY.

[51] Global Innovation Index. (2019). UAE compare to top countries regarding Creative goods and services (Score 0-100), INSEAD: The business school for the world.

[52] Haddad, A., Ameen, A., Isaac, O., Alrajawy, I., Al-Shbami, A., \& Midhun Chakkaravarthy, D. (2020). The Impact of Technology Readiness on the Big Data Adoption Among UAE Organisations. In N. Sharma, A. Chakrabarti, \& V. E. Balas (Eds.), Data Management, Analytics and Innovation (Vol. 1016, pp. 249-264). https://doi.org/https://doi.org/10.1007/978-981-139364-8_19

[53] Hair, J. F., Black, W. C., Babin, B. J., \& Anderson, R. E. (2010). Multivariate Data Analysis. New Jersey.

[54] Hair, J. F. J., Hult, G. T. M., Ringle, C., \& Sarstedt, M. A Primer on Partial Least Squares Structural Equation Modeling (PLS-SEM). , 46 Long Range Planning § (2014).

[55] Hannabarger, C., Buchman, F., \& Economy, P. (2011). Balanced Scorecard Strategy For Dummies. Wiley.

[56] Hassan, M. U., Malik, A. A., \& Hasnain, A. (2013). Measuring Employee Creativity and its Impact on Organization Innovation Capability and Performance in the Banking Sector of Pakistan. World Applied Sciences Journal, 24(7), 949-959. https://doi.org/10.5829/idosi.wasj.2013.24.07.13253

[57] Ibrahim, M., Sulaiman, M., Al Kahtani, A., \& Abu-Jarad, I. (2012). The relationship between strategy implementation and performance of manufacturing firms in Indonesia: The role of formality structure as a moderator. In World Applied Sciences Journal (Vol. 20). https://doi.org/10.5829/idosi.wasj.2012.20.07.2799

[58] Isaac, O., Masoud, Y., Samad, S., \& Abdullah, Z. (2016). The mediating effect of strategic implementation between strategy formulation and organizational performance within government institutions in Yemen. Research Journal of Applied Sciences, 11(10), 1002-1013. https://doi.org/10.3923/rjasci.2016.1002.1013 
Dhoha Younis, Divya Midhunchakkaravarthy, Osama Isaac, Ali Ameen, Balaganesh Duraisamy and Midhunchakkaravarthy Janarthanan

[59] Isaac, Osama, Abdullah, Z., Aldholay, A. H. A. H., Ameen, A., Abdulbaqi Ameen, A., \& Ramayah, T. (2019). Antecedents and Outcomes of Internet Usage within Organizations in Yemen: An extension of the Unified Theory of Acceptance and Use of Technology (UTAUT) Model. Business Process Management Journal, Emerald, 24(4), 335-354. https://doi.org/https://doi.org/10.1016/j.apmrv.2018.12.003

[60] Isaac, Osama, Abdullah, Z., Aldholay, A. H., \& Ameen, A. (2019). Antecedents and outcomes of internet usage within organisations in Yemen: An extension of the Uni fi ed Theory of Acceptance and Use of Technology (UTAUT) model. Asia Pacific Management Review, 1(1), 72-92. https://doi.org/10.1016/j.apmrv.2018.12.003

[61] Isaac, Osama, Abdullah, Z., Ramayah, T., \& Mutahar, A. M. (2017a). Internet usage , user satisfaction, task-technology fit, and performance impact among public sector employees in Yemen. The International Journal of Information and Learning Technology, 34(3), 210-241. https://doi.org/10.1108/IJILT-11-2016-0051

[62] Isaac, Osama, Abdullah, Z., Ramayah, T., \& Mutahar, A. M. (2017b). Internet Usage and Net Benefit among Employees Within Government Institutions in Yemen: An Extension of Delone and Mclean Information Systems Success Model (DMISM) with Task-Technology Fit. International Journal of Soft Computing, 12(3), 178-198. https://doi.org/10.3923/ijscomp.2017.178.198

[63] Isaac, Osama, Abdullah, Z., Ramayah, T., \& Mutahar, A. M. (2017c). Internet Usage within Government Institutions in Yemen: An Extended Technology Acceptance Model (TAM) with Internet Self-Efficacy and Performance Impact. Science International, 29(4), 737-747.

[64] Isaac, Osama, Abdullah, Z., Ramayah, T., \& Mutahar, A. M. (2018). Factors determining user satisfaction of internet usage among public sector employees in Yemen. International Journal of Technological Learning, Innovation and Development, 10(1).

[65] Isaac, Osama, Abdullah, Z., Ramayah, T., Mutahar, A. M., \& Alrajawy, I. (2017). Towards a Better Understanding of Internet Technology Usage by Yemeni Employees in the Public Sector: An Extension of the Task-Technology Fit (TTF) Model. Research Journal of Applied Sciences, 12(2), 205-223. https://doi.org/10.3923/rjasci.2017.205.223

[66] Isaac, Osama, Abdullah, Z., Ramayah, T., Mutahar, A. M., \& Alrajawy, I. (2018). Integrating User Satisfaction and Performance Impact with Technology Acceptance Model (TAM) to Examine the Internet Usage Within Organizations in Yemen. Asian Journal of Information Technology, 17(1), 60-78. https://doi.org/10.3923/ajit.2018.60.78

[67] Isaac, Osama, Abdullah, Z., Ramayah, T., \& Mutahar Ahmed, M. (2017). Examining the Relationship Between Overall Quality, User Satisfaction and Internet Usage: An Integrated Individual, Technological, Organizational and Social Perspective. Asian Journal of Information Technology, 16(1), 100-124. https://doi.org/10.3923/ajit.2017.100.124

[68] Isaac, Osama, Aldholay, A., Abdullah, Z., \& Ramayah, T. (2019). Online learning usage within Yemeni higher education: The role of compatibility and task-technology fit as mediating variables in the IS success model. Computers \& Education. https://doi.org/https://doi.org/10.1016/j.compedu.2019.02.012

[69] Jaiswal, N. K., \& Dhar, R. L. (2015). Transformational leadership, innovation climate, creative self-efficacy and employee creativity: A multilevel study. International Journal of Hospitality Management, 51(1), 30-41. https://doi.org/10.1016/j.ijhm.2015.07.002

[70] Johnson, G., Scholes, K., \& Whittington, R. (2008). Exploring Corporate Strategy. Financial Times Prentice Hall. 
The Moderation Impact of Personal Innovativeness on the Relationship between E-Learning Strategy Implementation and High Education Organizational Performance

[71] Jyoti, J., \& Dev, M. (2015). The impact of transformational leadership on employee creativity : the role of learning orientation. Journal of Asia Business Studies, 9(1), 78-98. https://doi.org/10.1108/JABS-03-2014-0022

[72] Kang, Y. C. (2006). Understanding the Applicability of Strategic Management in the Public Sector. New Jersey.

[73] Kaplan, R. S., \& Norton, D. P. (1996). strategic learning \& the balanced scorecard. Strategy \& Leadership, 24(5), 18-24. https://doi.org/10.1108/eb054566

[74] Kline, R. B. (2010). Principles and practice of structural equation modeling (3rd ed.). New York: The Guilford Press.

[75] Li, Z., Duverger, P., \& Yu, L. (2018). Employee creativity trumps supervisor-subordinate guanxi : Predicting prequitting behaviors in China's hotel industry. Tourism Management, 69(March), 23-37. https://doi.org/10.1016/j.tourman.2018.05.004

[76] Midhunchakkaravarthy, J., \& SelvaBrunda, S. (2020). Feature fatigue analysis of product usability using Hybrid ant colony optimization with artificial bee colony approach. The Journal of Supercomputing, 76(6), 3999-4016.

[77] Midhunchakkaravarthy, J., \& Brunda, S. S. (2019). A novel approach for feature fatigue analysis using HMM stemming and adaptive invasive weed optimisation with hybrid firework optimisation method. International Journal of Computer Aided Engineering and Technology, 11(4-5), 411-429.

[78] Midhunchakkravarthy, D., Balaganesh, D., Vivekanandam, V., \& Devaraj, A. (2020). A Survey on Feature Fatigue Analysis Using Machine Learning Approaches for Online Products. In Intelligent Computing and Innovation on Data Science (pp. 241-250). Springer, Singapore.

[79] Midhunchakkaravarthy, D. (2018). Product Usability and capability evaluation using modified BAT-ARM algorithm to alleviate feature fatigue. In 2018 IEEE conference-international conference on recent innovations in electrical, electronics \& communication engineering (ICRIEECE). IEEE.

[80] Michaela, A. (2011). Effective strategic action: from formulation to implementation. Nternational Conference on Economics, Business and Management. Manila, Philippines.

[81] MUCHIRA, W. N. (2013). RELATIONSHIP BETWEEN STRATEGY IMPLEMENTATION AND PERFORMANCE IN COMMERCIAL BANKS IN KENYA. UNIVERSITY OF NAIROBI.

[82] Mutahar, Ahmed M., Daud, N. M., Ramayah, T., Isaac, O., \& Alrajawy, I. (2017). Examining the intention to use mobile banking services in Yemen: an integrated perspective of technology acceptance model (TAM) with perceived risk and self-efficacy. Asian Journal of Information Technology, 15(12).

[83] Mutahar, Ahmed M, Mohd Daud, N., Ramayah, T., Isaac, O., \& Alrajawy, I. (2017). Integration of Innovation Diffusion Theory (IDT) and Technology Acceptance Model (TAM) to Understand Mobile Banking Acceptance in Yemen: The Moderating Effect of Income. International Journal of Soft Computing, 12(3), 164-177. https://doi.org/10.3923/ijscomp.2017.164.177

[84] Njagi, L., \& Kombo, H. (2014). Effect of Strategy Implementation on Performance of Commercial Banks in Kenya. European Journal of Business and Management, 6(13), 62-68. 
Dhoha Younis, Divya Midhunchakkaravarthy, Osama Isaac, Ali Ameen, Balaganesh Duraisamy and Midhunchakkaravarthy Janarthanan

[85] OWOLABI, S. A., \& MAKINDE, O. G. (2012). THE EFFECTS OF STRATEGIC PLANNING ON CORPORATE PERFORMANCE IN UNIVERSITY EDUCATION : A STUDY OF BABCOCK UNIVERSITY. Arabian Journal of Business and Management Review, 2(4), $27-$ 44.

[86] Richard, P. J., Devinney, T. M., Yip, G. S., \& Johnson, G. (2009). Measuring Organizational Performance: Towards Methodological Best Practice. Journal of Management, 35(3), 718-804. https://doi.org/10.1177/0149206308330560

[87] Ringle, C. M., Wende, S., \& Becker, J.-M. (2015). SmartPLS 3. Bonningstedt: SmartPLS.

[88] Schurer Coldiron, J. (2015). Strategic Management in Nonprofit Mental Health Service Organizations: Understanding Processes and Impact on Performance. https://doi.org/10.7936/K7862DMK

[89] Siddiqi, H., \& Qureshi, M. (2016). Research Issues in Social Sciences The Impact of Employees ' Creativity on the Performance of the Firm. Research Issues in Social Sciences, 1(1), 1-12.

[90] Sudhana, P., Ameen, A., \& Isaac, O. (2020). A multi-theoretical framework to better understand the college major choice in arts and design. Journal of Applied Research in Higher Education. https://doi.org/10.1108/JARHE-11-2019-0277

[91] Thomas, N. (2005). The Concise Adair on Creativity and Innovation.

[92] Vivekanandam, B., \& Rajesh Babu, M. (2019). Face Recognition from Video Frames Using Hidden Markov Model Classification Model Based on Modified Random Feature Extraction. Journal of Computational and Theoretical Nanoscience, 16(5-6), 2439-2447.

[93] Vivekanandam, B., \& Babu, M. R. (2018). A CREDIBLE WAY OF FACE RECOGNITION AND CLASSIFICATION SYSTEM IN VIDEO SCRUTINY. Journal of Web Engineering, 17(6), 3701-3714.

[94] Vivekanandam, B. (2016). 2Dr. M. Rajesh Babu,"MULTIPARTY ACCESS CONTROL FOR ONLINE SOCIAL NETWORKS". International Journal of Innovations in Scientific and Engineering Research (IJISER), 3(10), 73-76

[95] Wheelen, T. L., \& Hunger, J. D. (2012). Strategic Management and Business Policy: Cases. Prentice Hall.

[96] Yang, Y., Lee, P. K. C., \& Cheng, T. C. E. (2016). Int . J . Production Economics Continuous improvement competence, employee creativity, and new service development performance: A frontline employee perspective. Intern. Journal of Production Economics, 171, 275-288. https://doi.org/10.1016/j.ijpe.2015.08.006

[97] Zaei, M. E., Yarahmadzehi, M. H., \& Abtin, A. (2013). Strategic Management Practices in the Local Authorities : Factors Associated with Adoption of Strategic Management practices in the local authorities. INTERDISCIPLINARY JOURNAL OF CONTEMPORARY RESEARCH IN BUSINESS JULY, 5(3), 739-744.

\section{APPENDIX}

\section{Appendix A}

Instrument for varibles

\begin{tabular}{l|ll}
\hline Varible & Measure & Source \\
\hline
\end{tabular}


The Moderation Impact of Personal Innovativeness on the Relationship between E-Learning Strategy Implementation and High Education Organizational Performance

ST1: The implementation phase of the strategy is the most important stages of the strategic management process.

ST2: The pass process of implementation of the strategy in the light of the vision and mission directives.

Strategy

(ST) $\quad$ ST3: Administrative systems and communications support, incentives and decisions help the implementation of the strategy.

ST4: Providing information systems and control contribute to the effective implementation of the strategy.

SR1: Organization depend to initialize the structure in the implementation of the strategy.

SR2: Hierarchy within the organization is clear and established.

SR3: The roles and responsibilities are clearly established.

(SR) SR4: Current structure of the organization is appropriate to implement its strategic plans and goals.

Human

Resources

1: Organization builds human resource capacity and improve their performance.

HR2: Organization has concrete and realistic human resource plan.

HR3: There exists plan for staff training and development and improve their performance.

HR4: Organization regularly conducts performance appraisal and reviews.

INN1: If I heard about new information technology, I would look for ways to experiment

INN2: Among my peers, I am usually the first to explore new information technologies.

INN3: In general, I would not hesitate to try new things.

FI1: Represents the financial side in one of the most important priorities of the performance of senior management.

FI2: Organization's budget is enough to accomplish its strategy.

(FI)

FI3: No problem in financing the work of the organization and various programs.

FI4: Funding limits the department's ability to provide more services, higher quality.

FI5: The Organization is working to assess the impact of fiscal spending in different areas.

CU1: Customer segments vary with the organization economically and socially.

CU2: The organization concerned with the public's opinion of how the performance of its work and considers it a priority to them.

Customer $\quad$ CU3: Organization focused on fulfilling quality and speed required by the public.

CU4: Organization's reputation in the performance of its business and maintain a positive relationship with the public.

CU5: The organization with the public service office provides services in a positive way.

OE1: The internal operations focuses on transforming internal goals into reality.

OE2: The internal operating processes focus on the quality of the services provided to the public.

Operation $\quad$ OE3: The internal operating processes focuses in human resources and capacity (OE) development.

OE4: Internal operations focuses on business leadership and modern methods.

OE5: Internal operations develop channels of communication to facilitate the transfer of information.

LG1: Organization seeks to see what is new in the business world and apply it to their work.

LG2: Besides growth and education focuses on the department's ability to adapt to changing circumstances.

(O. Isaac et

al., 2016)

(Y.-M

Cheng, 2014)

(D. Cheng,

Liu, Qian, \&

Song, 2013)

(O. Isaac et

al., 2016) 